Original Article

\title{
Influence of Different Abutment Designs on the Biomechanical Behavior of One-Piece Zirconia Dental Implants and Their Surrounding Bone: A 3D-FEA
}

\author{
M. Shash ${ }^{a, b}$, H. Nazha ${ }^{a, b, *}$, W. Abbas ${ }^{c}$ \\ ${ }^{a}$ Faculty of Technical Engineering, University of Tartous, Tartous, Syria \\ ${ }^{\mathrm{b}}$ Faculty of Biomedical Engineering, Al-Andalus University for Medical Sciences, Tartous, Syria \\ ${ }^{\mathrm{c}}$ Faculty of Mechanical Engineering, Czech Technical University, Prague, Czech Republic
}

\section{H I G H L I G H T S}

- 3D finite element models were constructed for finite element analysis.

- The occlusal loading force was applied on the prosthetic abutments.

- The biomechanical behavior of the system was investigated.

- Model 01 presented the best biomechanical behavior in the peri-implant bone.

\section{A R T I C L E I N F O}

\section{Article history:}

Received 28 September 2018

Received in revised form 4 April 2019

Accepted 17 July 2019

Available online 5 August 2019

\section{Keywords:}

Dental implants

Abutment designs

Finite element analysis

Zirconia material

Biomechanical behavior

\section{G R A P H I C A L A B S T R A C T}

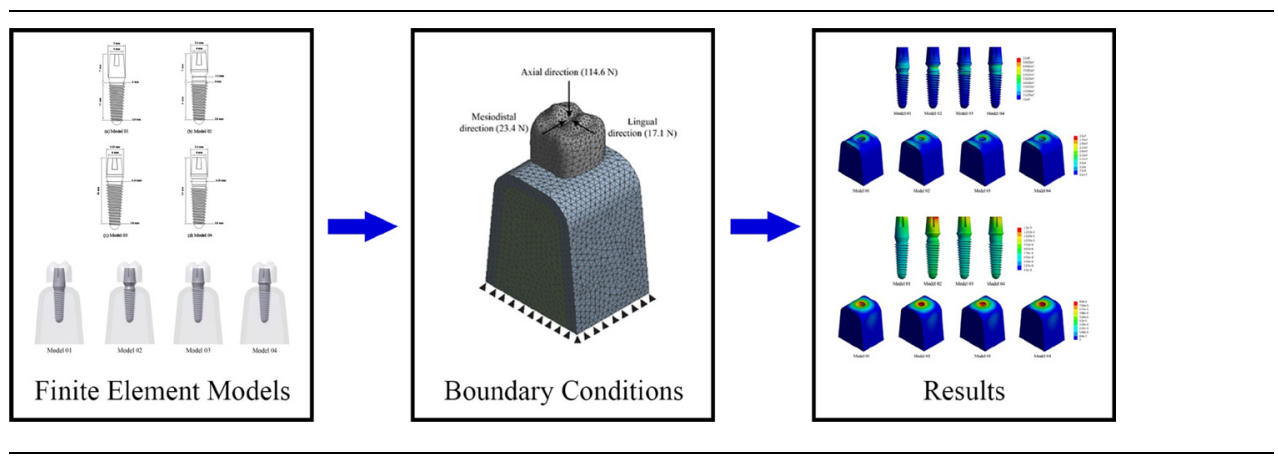

\section{A B S T R A C T}

Background: In a dental implant/bone system, the design factors affect the value and distributions of stress and deformations that plays a pivotal role on the stability, durability and lifespan of the implant/bone system.

Objective: The aim of this study was to compare the influence of different abutment designs on the biomechanical behavior of one-piece zirconia dental implants and their surrounding bone tissues using three-dimensional finite element analysis.

Methods: A three-dimensional geometrical model of a zirconia dental implant and its surrounding bone tissue were created. The occlusal loading force applied to the prosthetic abutments was a combination of $114.6 \mathrm{~N}$ in the axial direction, $17.1 \mathrm{~N}$ in the lingual direction and $23.4 \mathrm{~N}$ toward the mesial direction where these components represent masticatory force of $118.2 \mathrm{~N}$ in the angle of approximately $75^{\circ}$ to the occlusal plane.

Results: The system included implant abutment Model 01 showed a decrease of $9.58 \%, 9.92 \%$ and $3.62 \%$ at least in the average value of maximum von Mises stress compared to Model 02, Model 03 and Model 04 respectively. The results also showed that the system included implant abutment Model 01 decreases the average value of maximum deformation of $16.96 \%, 7.17 \%$ and $9.47 \%$ at least compared to Model 02 , Model 03 and Model 04 respectively.

Conclusion: The one-piece zirconia dental implant abutment Model 01 presents a better biomechanical behavior in the peri-implant bone than others. It can efficiently distribute the applied load and present more

\footnotetext{
* Corresponding author at: Faculty of Technical Engineering, University of Tartous, Tartous, Syria.

E-mail address: Hasannazha15@gmail.com (H. Nazha).
} 
homogeneous behavior of stress distribution and has less deformation than others, which will enhance the stability of implant/bone system and prolong its lifespan.

(c) 2019 AGBM. Published by Elsevier Masson SAS. All rights reserved.

\section{Introduction}

Implantation alludes to non-living materials into the body and set in living tissue [1]. Dental implant supported restorations have been generally utilized as a typical treatment method to restore edentulousness in recent years [2]. Numerous individuals have practiced with missing teeth implantation for removal. The essential treatment objective is the re-establishment of function. Further, objectives include the long-term functional stability of the implants, lessened surgical and prosthetic procedures, high predictability of the treatment results, and ideal structure design [3].

The transference of the occlusal loads to the bone-implant interface is a crucial factor to determine the result of the implant treatment [4]. Numerous factors influence load transfer at the bone-implant interface, for example, the type of loading, surface structure, amount of surrounding bone, material properties of the implant and implant design [5]. As the proper design can decrease the deformation, the stress or its distribution can be homogenized, it would be more likely to increase the success of the implant [6].

The kind of the load exerted on the implant influences the mode distribution of stress and the deformation. The excess applied load encompassing the implant causes very small cracks in the bone that leads to loosening and probable breaking of the implant. In term of implant material, a perfect implant material ought to be biocompatible, with suitable toughness, durability, corrosion, wear and fracture resistance [7]. The utilization of zirconia is concerned with the durability, corrosion resistance and aesthetics anticipation. Besides, Zirconia has been proven highly biocompatible in numerous investigations [8-10], and the gathering of bacteria has been reported lower than titanium [11]. Furthermore, the beforehand described animal investigations uncovered similar or even better bone growth onto zirconia when contrasted with titanium surfaces [12-14].

Some research focuses on failure of zirconia dental implant. Gahlert et al. [15] studied the failure mechanism of 13 fractured dental zirconia implants by clinical, macroscopic and scanning electron microscopic (SEM) methods. They found that $92 \%$ of the fractured implants were so-called diameter reduced implants (diameter $3.25 \mathrm{~mm}$ ), thus they concluded that these diameter reduced implants cannot be recommended for clinical use. Kammermeier et al. [16] studied zirconia dental implant systems. Their study was to investigate the long-term in vitro performance and fracture resistance of one-piece and bonded two-piece zirconia implant systems for anterior application. They found that bonded two-piece zirconia implant systems show more failure rates and lower fracture resistance than well-proven screwed two-piece titanium systems and hence may not be acceptable for clinical anterior necessaries. While Individual one-piece zirconia systems exhibit high variations in failure rates and fracture resistance and may in this manner be applied in anterior application.

Osman et al. [17] studied titanium versus zirconia implants to compare the stress and strain occurring in peri-implant bone and implants used to support maxillary overdentures where Threedimensional finite element analysis (3D FEA) was used to compare one-piece zirconia and titanium implants. They found that ceramic implants made from zirconia might be a potential alternative to conventional titanium implants for the support of overdentures. Pevida et al. [18] studied biomechanical consequences of the elastic properties of dental implant alloys on the supporting bone by finite element method, where the compared dental implants were made of rigid (Y-TZP), conventional (Ti-6Al-4V), and hyperelastic (Ti-Nb-Zr) materials. They found that rigid alloy (Y-TZP) dental implant produce less microdeformation in the peri-implant bone and implant itself compared to other materials. Wu et al. [19] used three-dimensional finite-element (FE) simulations to analyze the stresses in both the implant and the surrounding bone when using one-piece and two-piece small-diameter implants, with the aim of understanding the underlying biomechanical mechanisms. They found that the mechanical stress in the implant is higher in a two-piece small-diameter implant compared to one-piece smalldiameter implant.

In literature, biomechanical behavior has been analyzed to compare different dental implant materials, different designs based on diameter or length of implants, or one-piece versus two-piece dental implants. To our knowledge, this is the first investigation to underline the effect of different abutment designs on the biomechanical behavior of one-piece zirconia dental implants and their surrounding bone tissues. Therefore, the aim of this study is to validate, using 3D finite element method, the design concept by comparing the magnitude and distribution of stress and the deformation of peri-implant bone and the implant itself corresponding to four different abutment models of one-piece zirconia dental implants under static occlusal loads.

\section{Materials and methods}

\subsection{Modeling and meshing}

In this study, 3D FE models of mandibular sections of bone with a missing second premolar tooth are created. A bone block with dimensions of $15 \mathrm{~mm} \times 20 \mathrm{~mm} \times 15 \mathrm{~mm}$, representing the section of the mandible bone that consists of a cancellous bone surrounded by a 2-mm-thick layer of cortical bone in the upper part. Four different models of implant abutments with various geometries are specified in Fig. 1, where the 3D model of the implants was constructed by the Autodesk ${ }^{\circledR}$ Inventor ${ }^{\mathrm{TM}}$ software. Then, Models of the bone, the crown and the implant were exported to ANSYS ${ }^{\mathrm{TM}}$, where they were assembled into a single finite element (FE) model as shown in Fig. 2. Elements for FEA were tetrahedrons. The mesh was refined and accepted when the relative errors were less than $1 \%$. The results of convergence analysis are shown in Table 1 and Fig. 3.

\subsection{Boundary conditions}

The occlusal loading force applied to the crown is a combination of $114.6 \mathrm{~N}$ in the axial direction, $17.1 \mathrm{~N}$ in the lingual direction and $23.4 \mathrm{~N}$ toward the mesial direction where these components represent masticatory force of $118.2 \mathrm{~N}$ in the angle of approximately $75^{\circ}$ to the occlusal plane [20].

All the contacts modeled in this study are considered linear. The crown-abutment, The bone-bone and The bone-implant contact conditions established in this FEM analysis are considered bonded where the bone-implant interfaces are assumed to be bonded or osseointegrated $[1,17,21,22]$. The FEM model is fixed at the bottom surface of mandibular as shown in Fig. 4. 


\subsection{Material properties}

In the present study, the cortical and cancellous bone is considered orthotropic materials. The orthotropic materials exhibit different mechanical properties based on the loading direction, such as axial or transversal [23]. However, isotropic materials show the same mechanical properties regardless of loading direction [24].

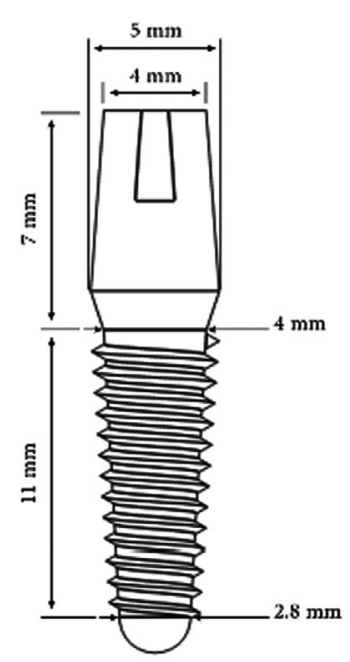

(a) Model 01

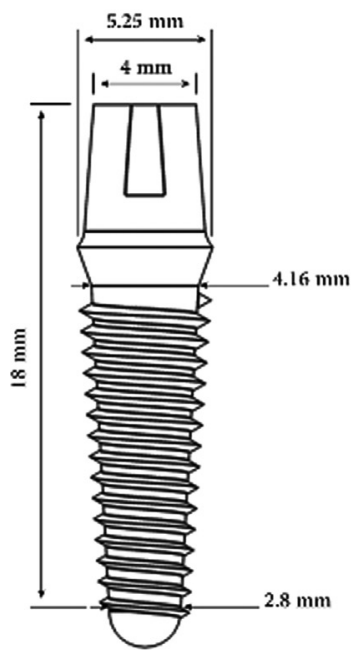

(c) Model 03

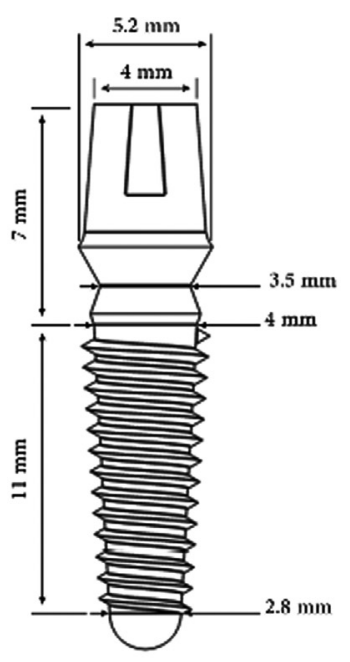

(b) Model 02

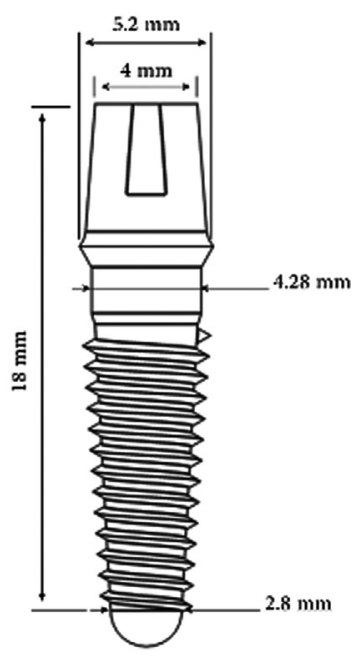

(d) Model 04

Fig. 1. Dimensions of the implant models used in the study.

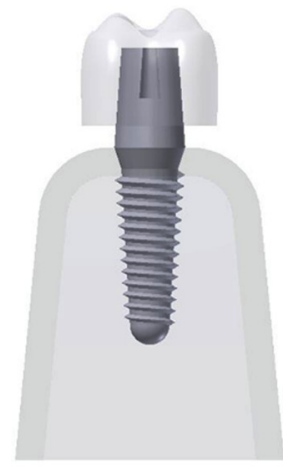

Model 01

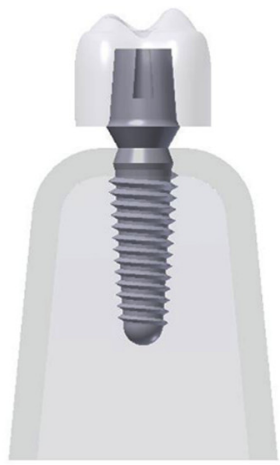

Model 02
The reference values are taken from the literature [25-31]. Table 2 shows a summary of the mechanical properties used in the numerical analysis.

\section{Results}

The data obtained from the finite element analysis can be presented in a deformation and stress distribution map with a color scale, which makes it possible to directly compare the magnitude and distribution of stress and the deformation of various zirconia dental implant models and surrounding bone tissues. These results demonstrate the relationship between the stress distribution in the implant/bone system, the geometrical characteristics of the abutment models and deformations.

One of the theories most used to determine the stress is von Mises theory. This theory has been applied to determine the stress distribution of the implant models and surrounding bone tissues. From the FE analysis, numerical results of maximum von Mises stress obtained for different models under static loading condition have been tabulated in Table 3 .

The stress in the implants is highest in the area near the first thread for all models as shown in Fig. 5. It could be observed that the von Mises stress of implant Model 02 (109.03 MPa) are much higher than those of other implants, while implant Model 04 (99.38 MPa) and Model 01 (100.59 MPa) have the lowest stress compared to other models. After the transferring of stress to the surrounding bones, the maximum stress in cortical bone is larger

Table 1

Total number of elements and nodes for each system.

\begin{tabular}{lllll}
\hline & Model 01 & Model 02 & Model 03 & Model 04 \\
\hline Elements & 53255 & 55281 & 63677 & 57615 \\
Nodes & 84839 & 87765 & 100278 & 91031 \\
\hline
\end{tabular}

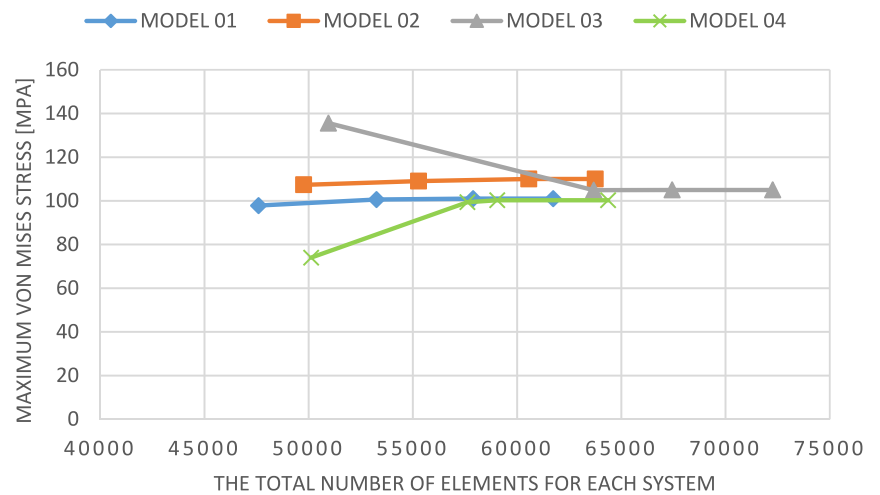

Fig. 3. Mesh sensitivity results in terms of the maximum von Mises stress.

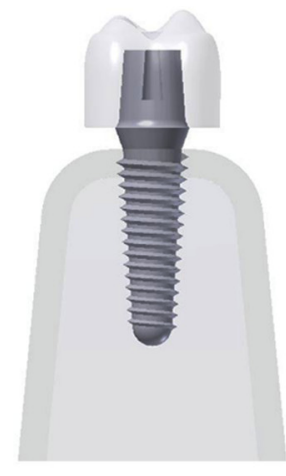

Model 03

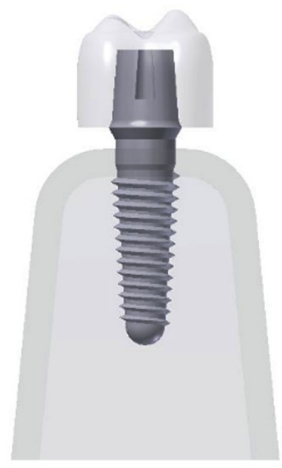

Model 04

Fig. 2. Assemblies including four models used in the study. 


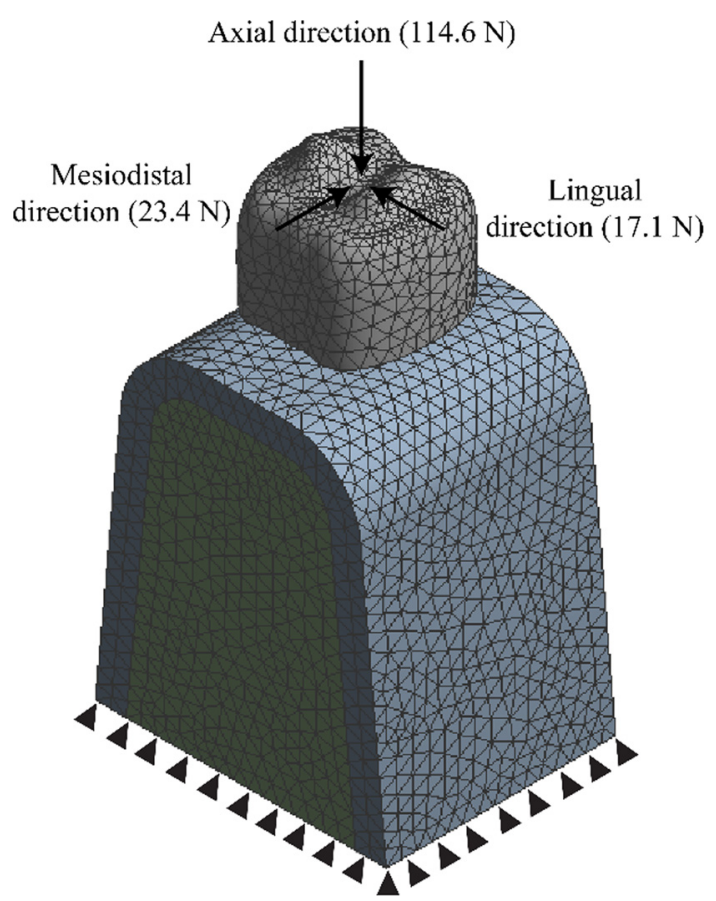

Fig. 4. Mesh and boundary conditions.

Table 2

Mechanical properties of the materials used in the study

\begin{tabular}{lllll}
\hline Properties & $\begin{array}{l}\text { Porcelain } \\
\text { crown }\end{array}$ & $\begin{array}{l}\text { Zirconia } \\
\text { (Y-TZP) }\end{array}$ & Cortical bone & $\begin{array}{l}\text { Cancellous } \\
\text { bone }\end{array}$ \\
\hline $\begin{array}{l}\text { Density } \\
{\left[\mathrm{g} / \mathrm{cm}^{3}\right]}\end{array}$ & 2.4 & 6.05 & 1.8 & 1.2 \\
$\begin{array}{l}\text { Elastic } \\
\text { modulus }\end{array}$ & 68900 & 205000 & $9600\left(E_{x}\right)$ & $144\left(E_{x}\right)$ \\
$\begin{array}{l}(E)[\mathrm{MPa}] \\
\text { Shear }\end{array}$ & & & $9600\left(E_{y}\right)$ & $99\left(E_{y}\right)$ \\
modulus & 26914 & 78846 & $17800\left(E_{z}\right)$ & $344\left(E_{z}\right)$ \\
$(G)[\mathrm{MPa}]$ & & & $3097\left(G_{x y}\right)$ & $53\left(G_{x y}\right)$ \\
& & & $3510\left(G_{y z}\right)$ & $63\left(G_{y z}\right)$ \\
$\begin{array}{l}\text { Poisson's } \\
\text { ratio }(v)\end{array}$ & 0.28 & 0.30 & $3510\left(G_{x z}\right)$ & $45\left(G_{x z}\right)$ \\
& & & $0.55\left(v_{x y}\right)$ & $0.23\left(v_{x y}\right)$ \\
& & & $0.30\left(v_{y z}\right)$ & $0.11\left(v_{y z}\right)$ \\
\hline
\end{tabular}

Table 3

Maximum von Mises stress in different implant models and surrounding bones.

\begin{tabular}{lllll}
\hline \multicolumn{2}{l}{ Von Mises stress $[\mathrm{MPa}]$} \\
\hline Description & Model 01 & Model 02 & Model 03 & Model 04 \\
\hline Implant & 100.59 & 109.03 & 104.88 & 99.38 \\
Cortical & 21.03 & 25.43 & 30.07 & 26.78 \\
Cancellous & 0.7 & 0.8 & 0.83 & 0.75 \\
\hline
\end{tabular}

than that of cancellous bone in the surrounding bone tissue as shown in Fig. 6. The highest von Mises stress is concentrated on the bone around the implant neck for all models. The implant/bone system included implant abutment Model 01 has the lowest stress at cortical (21.03 $\mathrm{MPa})$ and cancellous bone (0.7 $\mathrm{MPa})$ compared to others.

It is obvious that the design of the implant abutments has a predominate influence on the von Mises stress of bone-implant interface. Implant Model 02 has a high trend to cause the stress concentration, while implant Model 01 can efficiently reduce the interface stress.

In comparison of four implant/bone systems included various implant abutment models, it could be observed that Model 03 has the highest average value of maximum von Mises stress (45.26
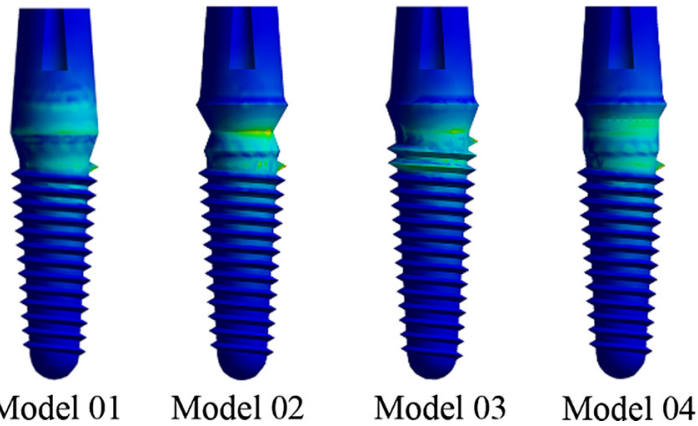

Fig. 5. Distribution of the stress in different implant models.

Table 4

Maximum total deformation in different implant models and surrounding bones.

\begin{tabular}{lllll}
\hline \multicolumn{2}{l}{ Total deformation $[\mu \mathrm{m}]$} & & & \\
\hline Description & Model 01 & Model 02 & Model 03 & Model 04 \\
\hline Implant & 9.76 & 12.43 & 10.8 & 11.05 \\
Cortical & 7.35 & 8.36 & 7.72 & 7.91 \\
Cancellous & 6.97 & 8.21 & 7.43 & 7.65 \\
\hline
\end{tabular}

MPa) as shown in Fig. 7, while Model 01 has the lowest average value of maximum von Mises stress (40.77 MPa) compared to other models.

Numerical results of total deformation of each model analyzed are listed in the Table 4 . Fig. 8 presents distribution of the deformation in different implant models. As shown, the value of the deformation decreases as the deformation position goes to the bottom of implant. The highest deformation is observed in the implant Model $02(12.43 \mu \mathrm{m})$, while the lowest deformation is found in the implant Model $01(9.76 \mu \mathrm{m})$. In the cortical bone, the highest deformation is observed in Model $02(8.36 \mu \mathrm{m})$ and the lowest in Model $01(7.35 \mu \mathrm{m})$ as shown in Fig. 9. Similar results are obtained for the cancellous bone, the highest deformation is found in Model $02(8.21 \mu \mathrm{m})$, but the lowest in Model $01(6.97 \mu \mathrm{m})$.

In comparison of four implant/bone systems included various implant abutment models, it could be observed that Model 02 has the highest average value of maximum deformation $(9.67 \mu \mathrm{m})$ as shown in Fig. 10, while Model 01 has the lowest average value of maximum deformation $(8.03 \mu \mathrm{m})$ compared to other models.

\section{Discussions}

In order to maintain the bone level or enhance the long-term success rates of implant system, a significant objective for dentists is to reduce the stress and deformation to the bone around the implant and the implant itself [19]. When implant/bone system is subjected to stresses, a few changes in form deformation may occur, where their points bear dislocations, being these, changes from the initial positions and between themselves [32].

FEA is a useful method to understand the biomechanical behaviors of restorative and prosthetic treatments under simulation of loading conditions in the oral environment [33]. Furthermore, it is a powerful approach to estimate the stress and deformation occurring in dental implants and surrounding bone. It is usually used to determine the forces that influence the bone-implant interface or to evaluate different clinical and prosthetic options [34-39].

In many studies, researches have employed FEA in conjunction with implant/bone system and made an effort to introduce a new design that can efficiently reduce the interface stress and deformation [17-19,40-43]. However, their work is limited to compare different dental implant materials, different designs based on diameter or length of implants, or one-piece versus two-piece dental implants. 


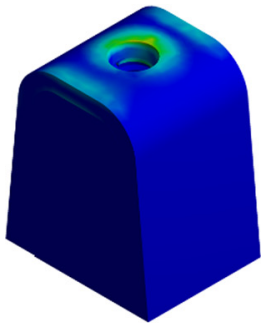

Model 01

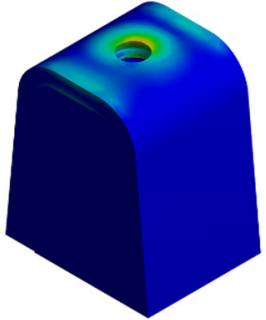

Model 02

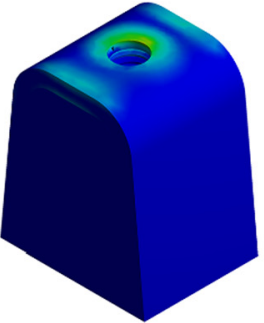

Model 03

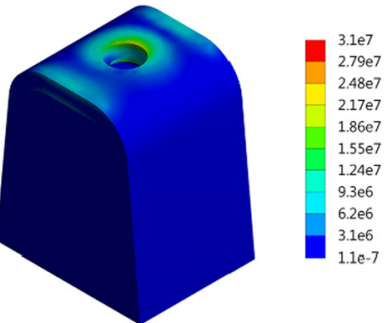

Model 04

Fig. 6. Distribution of the stress in the peri-implant bone.

Therefore, in the present work, a 3D FEA have employed on four different models of one-piece zirconia dental implant abutments to explore biomechanical behavior and compare the magnitude and distribution of stress and the deformation of peri-implant bone and the implant itself based on the geometrical characteristics of one-piece zirconia dental implant abutment models under static occlusal loads.

Since the von Mises stress is a combination of normal and shear stresses occurring in all directions, it is important to investigate it

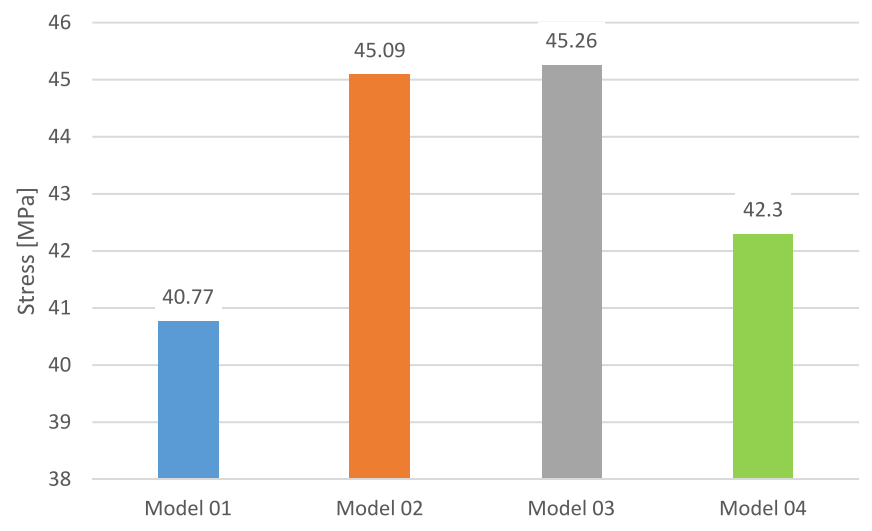

Fig. 7. Average values of maximum von Mises stress of different implant/bone systems included various abutment models.
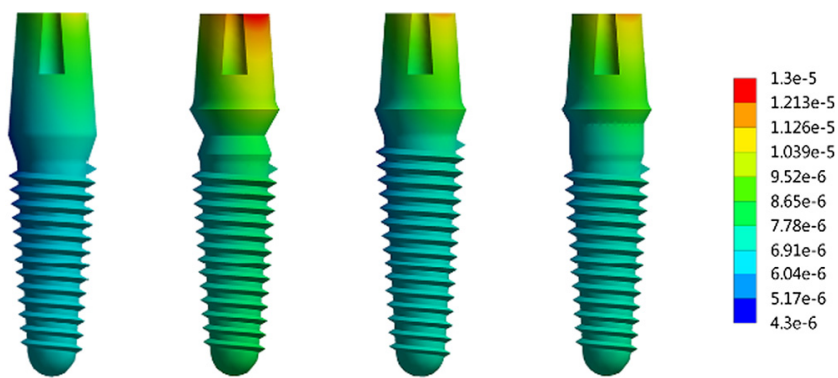

Model 01

\section{Model 03 Model 04}

Fig. 8. Distribution of the deformation in different implant models.

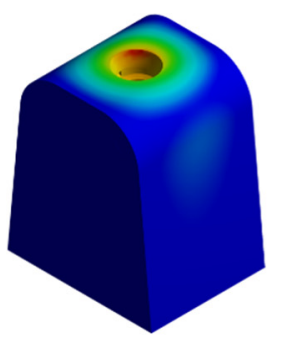

Model 01

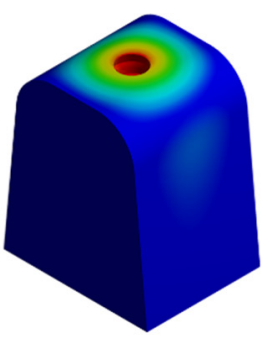

Model 02

in implant/bone systems [44]. From obtained numerical results, the system included implant abutment Model 01 showed a decrease of $9.58 \%, 9.92 \%$ and $3.62 \%$ at least in the average value of maximum von Mises stress compared to Model 02, Model 03 and Model 04 respectively as shown in Fig. 7. The results also showed that the system included implant abutment Model 01 decreases the average value of maximum deformation of $16.96 \%, 7.17 \%$ and $9.47 \%$ at least compared to Model 02, Model 03 and Model 04 respectively as shown in Fig. 10. These results achieved due to the abutment design that enable to distribute the applied load, thus the using of implant Model 01 will present more homogeneous behavior of stress distribution and has less deformation than others, it will also enhance the stability of implant/bone system and prolong its lifespan.

Since the diameter reduced implants cannot be recommended for clinical use due to its tendency to the failure [15], it is important to use the proper diameter implant that achieve the stability and load distribution in the system. Therefore, the use of implant Model 01 with $5 \mathrm{~mm}$ neck diameter seems to present a better performance in the system, so it could efficiently enhance the stability of implant/bone system, the stress distribution and prolong its lifespan.

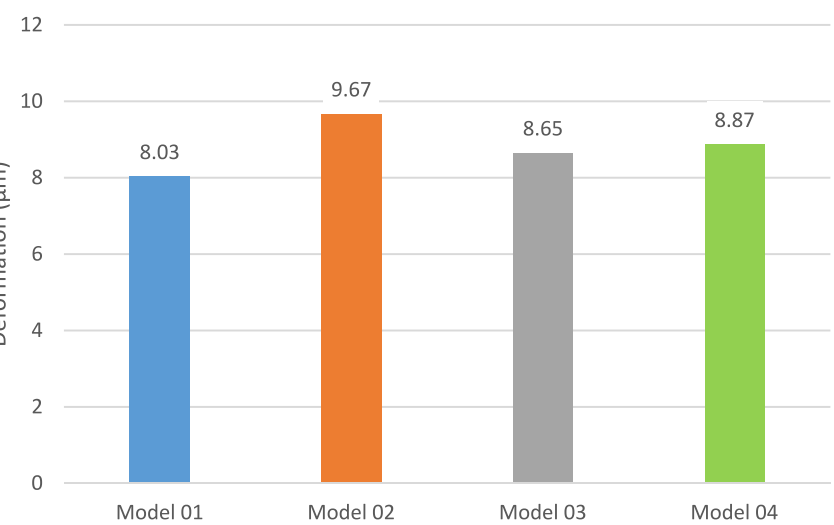

Fig. 10. Average values of maximum deformation of different implant/bone systems included various abutment models.

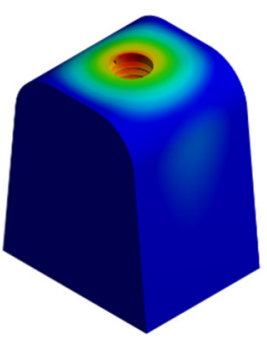

Model 03

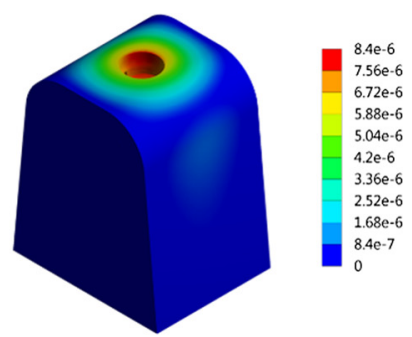

Model 04

Fig. 9. Distribution of the deformation in the peri-implant bone 
In this study, in order to achieve reliable data, the convergence and accuracy of the finite element results was examined, evaluated and validated. Two fundamental verifications were made; first, a mesh study to ensure about the size of mesh as previously mentioned and showed in Table 1 and Fig. 3. Second, a comparison with respect to an existing related work in literature regarding that no earlier studies have examined the influence of different abutment designs on the biomechanical behavior of one-piece zirconia dental implants and surrounding bone tissues.

Mahajan and Patil [45] showed that the stress in dental implant concentrated in the area near the first thread, while it concentrated on the bone around the implant neck. They also showed that the value of the deformation decreases as the deformation position goes to the bottom of implant, which was in agreement with the presented results in this study.

Gahlert et al. [15] showed that diameter reduced implants (diameter $3.25 \mathrm{~mm}$ ) have high failure risk caused by high concentrated stress, and Santiago et al. [46] found that the large-diameter implants (diameter $5 \mathrm{~mm}$ ) improved the transference of occlusal loads to bone tissue and decreased stress. These results were in agreement with the presented results, where the stress was the highest in the implant/bone system with abutment Model 02 (diameter $3.5 \mathrm{~mm}$ ), while the lowest stress was observed in the implant/bone system with abutment Model 01 (diameter $5 \mathrm{~mm}$ ), compared to Model 03 (diameter $4.16 \mathrm{~mm}$ ) and Model 04 (diameter $4.28 \mathrm{~mm}$ ).

Wu el al. [19] showed that the stress induced in zirconia dental implant is higher than bone stress. They also found that the stress in the cortical bone is higher than cancellous bone stress, that could be explained because the cortical bone has the tendency of concentrate greater strain [47]. Despite the fact that they studied two designs differ from the models studied in this research, this result was in agreement with the presented results.

Some limitations remain in the current study and must be taken into account in the model in order to optimize computational resources without affecting fundamental analysis. Given that the proposed design concept is based on implant/bone system with crown, the both of metal framework under the crown and cement layer were neglected. Perfect osseointegration between implants and bone was assumed and finite element analysis was performed under static occlusal loads. However, FEA is like any other basic research tool, which aids in planning further in vitro and in vivo tests when used as an initial step.

Nevertheless, as mentioned, the one-piece zirconia dental implant abutment Model 01 presents a better biomechanical behavior in the peri-implant bone than others. It can efficiently distribute the applied load and present more homogeneous behavior of stress distribution and has less deformation than others. That will enhance the stability of implant/bone system and prolong its lifespan.

\section{Conclusion}

Within the limitations of this study, it can be concluded that the one-piece zirconia dental implant abutment Model 01 can efficiently distribute the applied load in the implant/bone system and presents a more homogeneous behavior of stress distribution, and have less deformation than others. That will enhance the stability, durability and lifespan of the system. Further investigations studying the models under dynamic loadings are required to achieve a better understanding of the biomechanical behavior.

\section{Funding}

This work did not receive any grant from funding agencies in the public, commercial, or not-for-profit sectors.

\section{Author contributions}

All authors attest that they meet the current International Committee of Medical Journal Editors (ICMJE) criteria for Authorship.

\section{Declaration of Competing Interest}

The authors declare that they have no known competing financial or personal relationships that could be viewed as influencing the work reported in this paper.

\section{CRediT authorship contribution statement}

M. Shash: Conceptualization, Formal analysis, Supervision, Validation, Visualization, Writing - original draft, Writing - review \& editing. H. Nazha: Conceptualization, Formal analysis, Supervision, Validation, Visualization, Writing - original draft, Writing - review \& editing. W. Abbas: Conceptualization, Formal analysis, Supervision, Validation, Visualization, Writing - original draft, Writing review \& editing.

\section{References}

[1] Yeşildal R, Karabudak F, Bayındır F, Zamanlou H, Yıldırım M, Sağsöz N, et al Effect of implant diameter and length on stress distribution for titanium and zirconia implants by using finite element analysis (FEA). Open Access Libr J 2015;2:1-7. https://doi.org/10.4236/oalib.1101211.

[2] Topkaya T, Solmaz MY, Dündar S, Eltas A. Numerical analysis of the effect of implant geometry to stress distributions of the three different commercial dental implant system. Cumhuriyet Dent J 2015;18:17-24. https://doi.org/10.7126/ cdj.58140.5000037693.

[3] Buser D, Belser UC, Lang NP. The original one-stage dental implant system and its clinical application. Periodontol 2000 1998;17:106-18. https://doi.org/ 10.1111/j.1600-0757.1998.tb00128.x.

[4] Cehreli M, Duyck J, De Cooman M, Puers R, Naert I. Implant design and interface force transfer. A photoelastic and strain-gauge analysis. Clin Oral Implants Res 2004;15:249-57. https://doi.org/10.1111/j.1600-0501.2004.00979.x.

[5] Geng JP, Tan KBC, Liu GR. Application of finite element analysis in implant dentistry: a review of the literature. J Prosthet Dent 2001;85:585-98. https:// doi.org/10.1067/mpr.2001.115251.

[6] Zarei I, Khajehpour S, Sabouri A, Haghnegahdar AZ, Jafari K. Assessing the effect of dental implants thread design on distribution of stress in impact loadings using three dimensional finite element method. J Dent Biomater 2016;3:233-40

[7] Osman RB, Swain MV. A critical review of dental implant materials with an emphasis on titanium versus zirconia. Materials 2015;8:932-58. https:// doi.org/10.3390/ma8030932.

[8] Ichikawa Y, Akagawa Y, Nikai H, Tsuru H. Tissue compatibility and stability of a new zirconia ceramic in vivo. J Prosthet Dent 1992;68:322-6. https://doi.org/ 10.1016/0022-3913(92)90338-B.

[9] Manicone PF, Iommetti PR, Raffaelli L. An overview of zirconia ceramics: basic properties and clinical applications. J Dent 2007;35:819-26. https://doi.org/10. 1016/j.jdent.2007.07.008.

[10] Hsu SK, Hsu HC, Ho WF, Yao CH, Chang PL, Wu SC. Biomolecular modification of zirconia surfaces for enhanced biocompatibility. Thin Solid Films 2014;572:91-8. https://doi.org/10.1016/j.tsf.2014.07.068.

[11] Al-Radha ASD, Dymock D, Younes C, O'Sullivan D. Surface properties of titanium and zirconia dental implant materials and their effect on bacterial adhesion. J Dent 1992;40:146-53. https://doi.org/10.1016/j.jdent.2011.12.006.

[12] Schultze-Mosgau S, Schliephake H, Radespiel-Tröger M, Neukam FW. Osseointegration of endodontic endosseous cones zirconium oxide vs titanium. Oral Surg Oral Med Oral Pathol Oral Radiol Endo 2000;89:91-8. https://doi.org/10. 1016/S1079-2104(00)80022-0.

[13] Akagawa Y, Ichikawa Y, Nikai H, Tsuru H. Interface histology of unloaded and early loaded partially stabilized zirconia endosseous implant in initial bone healing. J Prosthet Dent 1993;69:599-604. https://doi.org/10.1016/00223913(93)90289-Z.

[14] Akagawa Y, Hosokawa R, Sato Y, Kamayama K. Comparison between freestanding and tooth-connected partially stabilized zirconia implants after two years' function in monkeys: a clinical and histologic study. J Prosthet Dent 1998;80:551-8. https://doi.org/10.1016/S0022-3913(98)70031-9.

[15] Gahlert M, Burtscher D, Grunert I, Kniha H, Steinhauser E. Failure analysis of fractured dental zirconia implants. Clin Oral Implants Res 2012;23:287-93. https://doi.org/10.1111/j.1600-0501.2011.02206.x. 
[16] Kammermeier A, Rosentritt M, Behr M, Schneider-Feyrer S, Preis V. In vitro performance of one- and two-piece zirconia implant systems for anterior application. J Dent 2016;53:94-101. https://doi.org/10.1016/j.jdent.2016.08.004.

[17] Osman RB, Elkhadem AH, Ma S, Swain MV. Titanium versus zirconia implants supporting maxillary overdentures: three-dimensional finite element analysis. Int J Oral Maxillofac Implants 2013;28. https://doi.org/10.11607/jomi.3019.

[18] Pérez-Pevida E, Brizuela-Velasco A, Chávarri-Prado D, Jiménez-Garrudo A Sánchez-Lasheras F, Solaberrieta-Méndez E, et al. Biomechanical consequences of the elastic properties of dental implant alloys on the supporting bone: finite element analysis. BioMed Res Int 2016;2016. https://doi.org/10.1155/2016 1850401.

[19] Wu AYJ, Hsu JT, Chee W, Lin YT, Fuh LJ, Huang HL. Biomechanical evaluation of one-piece and two-piece small-diameter dental implants: in-vitro experimental and three-dimensional finite element analyses. J Formos Med Assoc 2016;115:794-800. https://doi.org/10.1016/j.jfma.2016.01.002.

[20] Kayabasi O, Yüzbasioglu E, Erzincanli F. Static, dynamic and fatigue behaviors of dental implant using finite element method. J Adv Eng Softw 2006;37:649-58. https://doi.org/10.1016/j.advengsoft.2006.02.004.

[21] Cicciù M, Cervino G, Bramanti E, Lauritano F, Lo Gudice G, Scappaticci L, et al. FEM analysis of mandibular prosthetic overdenture supported by dental implants: evaluation of different retention methods. Comput Math Methods Med 2015;2015. https://doi.org/10.1155/2015/943839.

[22] Chen LJ, Hao HE, Li YM, Ting LI, Guo XP, Wang RF. Finite element analysis of stress at implant-bone interface of dental implants with different structures. Trans Nonferr Met Soc China 2011;21:1602-10. https://doi.org/10.1016/S1003 6326(11)60903-5.

[23] Elhamian SMM, Alizadeh M, Shokrieh MM, Karimi A. A depth dependent transversely isotropic micromechanic model of articular cartilage. J Mater Sci, Mater Med 2015;26:1-10. https://doi.org/10.1007/s10856-015-5449-8.

[24] Shahmohammadi M, Shirazi HA, Karimi A, Navidbakhsh M. Finite element simulation of an artificial intervertebral disk using fiber reinforced laminated composite model. Tissue Cell 2014;46:299-303. https://doi.org/10.1016/j.tice.2014. 05.008.

[25] Chen J, Lu X, Paydar N, Akay HU, Roberts WE. Mechanical simulation of the human mandible with and without an endosseous implant. Med Eng Phys 1994;16:53-61. https://doi.org/10.1016/1350-4533(94)90011-6.

[26] Park J, Lakes RS. Biomaterials: an introduction. Springer Science \& Business Media; 2007.

[27] Cicciù M, Beretta M, Risitano G, Maiorana C. Cemented-retained vs screwretained implant restorations: an investigation on 1939 dental implants. Minerva Stomatol 2008;57:167-79.

[28] Michailidis N, Karabinas G, Tsouknidas A, Maliaris G, Tsipas D, Koidis P. A FEM based endosteal implant simulation to determine the effect of periimplant bone resorption on stress induced implant failure. Bio-Med Mater Eng 2013;23:317-27. https://doi.org/10.3233/BME-130756.

[29] Holmgren EP, Seckinger RJ, Kilgren LM, Mante F. Evaluating parameters of osseointegrated dental implants using finite element analysis-a two-dimensional comparative study examining the effects of implant diameter, implant shape, and load direction. J Oral Implantol 1998;24:80-8. https://doi.org/10.1563 1548-1336(1998)024<0080:EPOODI>2.3.CO;2.

[30] Covani U, Ricci M, Tonelli P, Barone A. An evaluation of new designs in implantabutment connections: a finite element method assessment. Implant Dent 2013;22:263-7. https://doi.org/10.1097/ID.0b013e318292625f.

[31] Chowdhury AR, Pal S. A 3-D FEM analysis of single and multiple screw-root dental implant fixed in a mandible. Crit Rev Biomed Eng 2000;28:405-10

32] Borie E, Orsi IA, Noritomi PY, Kemmoku DT, Borie E, Orsi I, et al. Total deformation of multiple implant-supported prostheses through three-dimensional finite element analysis. Int J Odontostomat 2015;9:437-42. https://doi.org/10. 4067/S0718-381X2015000300013.

[33] Farah JW, Craig RG. Finite element stress analysis of a restored axisymmetric first molar. J Dent Res 1974;53:859-66. https://doi.org/10.1177/ 00220345740530041701.

[34] Bozkaya D, Muftu S, Muftu A. Evaluation of load transfer characteristics of five different implants in compact bone at different load levels by finite elements analysis. J Prosthet Dent 2004;92:523-30. https://doi.org/10.1016/ S0022391304004901.

[35] Petrie CS, Williams JL. Comparative evaluation of implant designs: influence of diameter, length, and taper on strains in the alveolar crest. A three-dimensional finite-element analysis. Clin Oral Implants Res 2005;16:486-94. https://doi.org/ 10.1111/j.1600-0501.2005.01132.x.

[36] Chun HJ, Cheong SY, Han JH, Heo SJ, Chung JP, Rhyu IC, et al. Evaluation of design parameters of osseointegrated dental implants using finite element analysis. J Oral Rehabil 2002;29:565-74. https://doi.org/10.1046/j.1365-2842.2002. 00891.x.

[37] Tada S, Stegaroiu R, Kitamura E, Miyakawa O, Kusakari H. Influence of implant design and bone quality on stress/strain distribution in bone around implants: a 3-dimensional finite element analysis. Int J Oral Maxillofac Implants 2003;18:357-68.

[38] Moiduddin K, Anwar S, Ahmed N, Ashfaq M, Al-Ahmari A. Computer assisted design and analysis of customized porous plate for mandibular reconstruction. IRBM 2017;38:78-89. https://doi.org/10.1016/j.irbm.2017.01.003.

[39] Plantefève R, Peterlik I, Cotin S. Intraoperative biomechanical registration of the liver: does the heterogeneity of the liver matter? IRBM 2018;39:18-25. https:/ doi.org/10.1016/j.irbm.2017.10.005.

[40] Moreira W, Hermann C, Pereira JT, Balbinoti JA, Tiossi R. A three-dimensional finite element study on the stress distribution pattern of two prosthetic abutments for external hexagon implants. Eur J Dent 2013;7:484-91. https://doi. org/10.4103/1305-7456.120642.

[41] Akça K, Cehreli MC, Iplikçioğlu H. Evaluation of the mechanical characteristics of the implant-abutment complex of a reduced-diameter morse-taper implant. A nonlinear finite element stress analysis. Clin Oral Implants Res 2003;14:444-54. https://doi.org/10.1034/j.1600-0501.2003.00828.x.

[42] Ao J, Li T, Liu Y, Ding Y, Wu G, Hu K, et al. Optimal design of thread height and width on an immediately loaded cylinder implant: a finite element analysis. Comput Biol Med 2010;40:681-6. https://doi.org/10.1016/j.compbiomed.2009. 10.007.

[43] Ausiello P, Franciosa P, Martorelli M, Watts DC. Effects of thread features in osseo-integrated titanium implants using a statistics-based finite element method. Dent Mater 2012;28:919-27. https://doi.org/10.1016/j.dental.2012.04. 035.

[44] Beer FP, Johnston ER. Mechanics of materials. New York: McGraw-Hill; 1981.

[45] Mahajan S, Patil R. Application of finite element analysis to optimizing dental implant. Int J Res Eng Technol 2016;3:850-6.

[46] Junior JFS, Pellizzer EP, Verri FR, De Carvalho PSP. Stress analysis in bone tissue around single implants with different diameters and veneering materials: a 3-D finite element study. Mater Sci Eng C 2013;33:4700-14. https:// doi.org/10.1016/j.msec.2013.07.027.

[47] Dos Santos Marsico V, Lehmann RB, De Assis Claro CA, Amaral M, Vitti RP, Neves ACC. Three-dimensional finite element analysis of occlusal splint and implant connection on stress distribution in implant-supported fixed dental prosthesis and peri-implantal bone. Mater Sci Eng C 2017;80:141-8. https:/ doi.org/10.1016/j.msec.2017.05.071. 